\title{
Studying on the Relational Investments and Customer Loyalty of the Third Party Logistics Enterprise
}

\author{
Yihua YANG \\ Guangzhou Institute of Railway Technology, Guangzhou 510430
}

\begin{abstract}
This paper put TPL relational investments into three types: economic relational investments structural relational investments, Chinese-style relational investments. Through empirical research, we drew the following conclusions: there was U shape correlation between economic relational of TPL enterprise and customer loyalty; there was a positive correlation between structural relational investments of TPL enterprise and customer loyalty; There was a positive correlation between Chinese-style relational investments and customer loyalty. In practical significance to the enterprise: Economic relational investments of TPL enterprise should have a good grasp of degree, not over do sth.; structural relational investments of TPL enterprise sustainable strengthening; Chinese-style relational investments is required to continue to strengthen in the framework of moral and law, can continuously improve customer loyalty.

KEYWORD: TPL enterprise; Economic relational investments; Structural relational investments; Chinesestyle relational investments; Customer loyalty
\end{abstract}

\section{INSTRUCTIONS}

As competition intensifies, many enterprises outsource their non-core logistics to the third-party logistics service providers (TPLSP) for maintaining their core competencies, through outsourcing, production companies not only can save logistics costs, but also can improve the operational efficiency and flexibility of the logistics system, thus providing more specialized logistics services to improve customer loyalty purposes. There is the basis of coordination and cooperation for third-party logistics (TPL) relational investments between business and customer: in the contract period, benefit allocation of both sides will be resolved basing on agreement, interest conflict of both sides will be resolved basing on agreements after two sides reaching an logistics outsourcing agreement. When logistics services' level from TPLSP meet or exceed customer expectations, customer satisfaction improved, and thus company's products to customers will lead to greater market demand, customers achieve business revenues and profits growth. Therefore, this is a community of interests between TPLSP and client companies.

We found from the above description, Although TPL enterprise development rapidly in logistics industry and share of more and more possession, but the competition is fierce, many scholars' study shows that TPL enterprise customer relational investments are both basis for coordination and cooperation thus TPL enterprises can only increasing the customer relational investments to improve the satisfaction and loyalty, and thus retaining customers to increase market share and profits.

\section{LITERATURE REVIEW AND RESEARCH HYPOTHESISR}

\section{$2.1 T P L$ relational investments}

Balakrishnan, A, \& Geunes, J. (2004) argued that relational investments are resources, effort and attention which own external value[1]. Hart (1998) regarded relational investment as a specificrelational investments, he believes the specificrelational investments as an initial investment, if the bilateral economic relational continuating long-term, it can create value, if the relational breakdown, it does not create value.

This paper argues that the relational investments are tangible or intangible resources for customers to pay to enable third-party logistics companies with its customers to maintain a strategic partnership.

In terms of the type of relational investments, many study have shown a link between relational investments and relational bond, Classification of the relational bond by Bensaou M, Anderson E 
(1999) is considered to be the most complete and comprehensive[2]. Berry and Parasuraman divided relational bond into three levels: the financial level, the financial + social hierarchy, finance + social + structural level, currently, the majority of scholars studying relational bond classification relational bond basically follow-financial bonds, structured ties and social ties classification methods (Lin et, 2003)[3]. Therefore, This paper classify relational investment into three types based on relational bond classification: the firstly is the economic relational investment which provide customers with "affordable" investment; the secondly is structural relational investment: mainly to formed some of the rules, the establishment of an atmosphere and environment in the process of interaction with customers ; the thirdly is Chinese-style relational investments, which is relationals border management under the Chinese local culture .

\subsection{Customer loyalty theory}

\subsubsection{The concept of customer loyalty}

Frederick and Schefter (2000) believed that customer loyalty concept refers to win the trust of customers, that is win investment clients, own customer relationals commitment[4]. Peltier and Westfall (2000) believed that customer loyalty include attitudes, intentions, or the possibility behavioral cognitive (perspective), therefore need multiple indicators to measure loyalty[5]. Ganesh, Arnold, and Reynolds (2000) defined customer loyalty as a positive enterprise emotional state, Dick and Basu (1994), Singh and Sirdeshmukh (2000) believed that customer loyalty is an expression of conscious consumer behavior. Colwell et al (2006) summarize the results of previous studies on the basis of customer loyalty will be defined as: customer loyalty is the consumer's emotional expression of positive affirmation companies and in the future to keep the business dealings of behavioral intentions[6].

\subsubsection{Factors Affecting customer loyalty}

We found that impact factors of customer loyalty are customer satisfaction, customer perceived value, transfer costs, customer trust and so on by studying of the literature. (1) Customer Satisfaction: An Empirical Study of American scholars Banwari and Walfried done in 1998 showed that it is a significant positive correlation between customer satisfaction and customer loyalty. Chinese scholars Xiaoyun Hang suggest that customer satisfaction will not only directly affect customer loyalty, but also indirectly affect customer loyalty through some intermediate variables. (2) Customer trust: trust itself is not an act, nor is it an option, but a potential state from these activities, Therefore, trust is a prerequisite for long-term cooperation. (3) Conversion costs: Conversion costs is called exit fence, exit barriers by some scholars. Conversion costs are effectively prevent customers from leaving business by setting up barriers, suppliers, customers and the relational that exists between the two are likely to generate conversion costs. When studying the effects of factors, many scholars (Jones et. al., 2002 Colgate \& Lang, 2001) found that conversion costs are positively related to customer loyalty; (3) Customer perceived value: It refers to the relative value of the customer to the supplier of a subjective evaluation. Customer delivered value is higher, customers own more satisfied, and more loyal.

\subsection{Research hypothesis}

\subsubsection{The impact of economic relatio-nal investment on customer loyalty}

Economic relational investment can bring customers "benefits" of inves-ment, which corresponds to financial bond of relational bond, and price concessions are widely used economy investment strategy in TPL enterprise. Many scholars analyzed the relationship between price and customer loyalty. Grewal etal (1998) argued that economic relational investment can make trading volume increase of a service provider's in the short term, but in the longterm, it will have a negative impact on quality of brand and the internal reference price. In Chinese logistics market, put economy as a strategy studying extremely common on the market staff, NO available tools is more powerful than economic inputs, thus the price of customer's purchase behavior has a significant impact on corporate profits. But Grewa, Krishnan and Flynn's research found that economic investment only a short-term nature, it presented a great challenge in the future development of enterprises as a marketing tool basing on rationality and customer loyalty to acquisition strategy . Therefore, we can make the following assumptions:

Assumption 1: There was $U$ shape correlation between economic relational of TPL enterprise and customer loyalty.

\subsubsection{The impact of structural relational investment on customer relational loyalty}

Structural relational investment points to form some rules to establish an atmosphere and environment, which bilateral establish exchanges norms in the process of interaction with customers,cit correspondences to structural bond of relational bond.

Qianli Dong (2000) proposed that structural relational investment can effectively reduce the cooperation risk[7]. Xuemei Fan (2012) also proposed that contract controls limited opportunistic behavior basing on transaction cost theory and 
incomplete contract theory[8]. In most cases, difficult partnership based on precise measurements of betrayal and the height of the conversion process understanding, TPL enterprises tend to use a variety of structural inputs, such as behavioral control methods to control the customer relational risk. In this sense, the structural relational between inputs can effectively reduce the risk of customer defection, improve customer loyalty.

So you can make the following assumptions:

Assumption 2: There was a positive correlation between structural relational investments of TPL enterprise and customer loyalty;

\subsubsection{The impact of Chinese-style relationals investment on customer relational loyalty}

Chinese-style relational investment is interpersonal relational investment to management border of TPL under Chinese local culture, which corresponds to social bond of relational bond. The importance of Chinese-style relational investment has been proven by lots of institute. Relationship is considered to the most important element by Chinese in real life, none can exist if leaving Chinese relations system, from politics to economics, from officials to the poor, it is an effective way to achieve a variety of purposes of relational investment. Therefore, relational investment is most importance in Chinese market, Tung and Worm pointed out that relational investment will continue to play a prominence role of in Chinese society, widespread, deep-rooted, therefore, the relational investment should be increased as a theoretical and practical foundation to research of customer loyalty. Therefore, we can make assumptions:

Hypothesis 3: There was a positive correlation between Chinese-style relationals investment and customer loyalty.

\section{RESEARCH METHODS}

\subsection{Research Steps}

This study is a survey research method. In order to study these problems and validate hypotheses, we refer to researching of Chinese and foreign scholars, and make a questionnaire, using the questionnaire collect data. Research process includes the following four steps: (1) review the literature of TPL relational investment and customer loyalty, and put forward hypotheses basing theoretical level ; (2) development of appropriate questionnaires, including the division of specific dimensions and issues select; (3) data collection and analysis, including issuance of questionnaires, recycling, data entry, and the test of reliability and validity; (4) verification authenticity of assumption, using correlation analysis, variance analysis and regression analysis to explore TPL relationship between relational investment and customer loyalty .

\subsection{Questionnaire Design}

Being most of the variables involved in this paper are difficult to quantify, this paper uses five scales to measure scoring method. 1-5 represents the "from totally inconsistent to totally inconsistent" transition, which "1" indicates totally inconsistent, "2" indicates does not basically conform, "3" represents the neutrality attitude, "4" in line, "5" denotes fully comply.

\subsection{Data Collection}

This study used questionnaires for data collection, due to the conditions, the sampling method used is the snowball sampling method, this research methodology in obtaining detailed information of enterprises is very necessary. Respondents in Guangdong Province Association of logistics managers and some employees. A total of 220 questionnaires distributed, 186 were recovered, in addition to throwing eight invalid questionnaires, the final total of 178 valid questionnaires. Using a statistical software SPSS 16.0. The basic data are described in Table 1.

\subsection{Impact of third-party logistics companies investing in customer relational loyalty}

This paper analyzes the impact of third-party logistics companies investing in customer loyalty relational, involving variables (independent variables: economic relational investments ERI, structural relational investment SRI and Chinese relations investment CRI. Dependent variable: customer loyalty CL) mean, standard error, and the correlation coefficient, all are given in table 1 and Table 2.

Table 1 describes the statistical analysis

\begin{tabular}{|c|c|c|c|}
\hline Variable & Mean & Standard Deviation & N \\
\hline ERI & 3.5195 & 0.60656 & 171 \\
\hline SRI & 3.4286 & 0.59691 & 171 \\
\hline CRI & 3.2594 & 0.47699 & 171 \\
\hline CL & 3.7105 & 0.61319 & 171 \\
\hline
\end{tabular}


Table 2 correlation coefficient table

\begin{tabular}{|c|c|c|c|c|c|}
\hline & & ERI & SRI & CRI & $\mathrm{CL}$ \\
\hline \multirow{3}{*}{ ERI } & $\begin{array}{c}\text { Pearson } \\
\text { correlation }\end{array}$ & 1 & $0.655 * *$ & $0.427 * *$ & $0.552 * *$ \\
\hline & $\begin{array}{c}\text { Significant } \\
\text { (bilateral) }\end{array}$ & & 0.000 & 0.000 & 0.000 \\
\hline & $\mathrm{N}$ & 171 & 171 & 171 & 171 \\
\hline \multirow{3}{*}{ SRI } & $\begin{array}{c}\text { Pearson } \\
\text { correlation }\end{array}$ & $0.655^{* *}$ & 1 & $0.396 * *$ & $0.565 * *$ \\
\hline & $\begin{array}{c}\text { Significant } \\
\text { (bilateral) }\end{array}$ & 0.000 & & 0.000 & 0.000 \\
\hline & $\mathrm{N}$ & 171 & 171 & 171 & 171 \\
\hline \multirow{3}{*}{ CRI } & $\begin{array}{l}\text { Pearson } \\
\text { correlation }\end{array}$ & $0.427 * *$ & $0.396 * *$ & 1 & $0.362 * *$ \\
\hline & $\begin{array}{c}\text { Significant } \\
\text { (bilateral) }\end{array}$ & 0.000 & 0.000 & & 0.000 \\
\hline & $\mathrm{N}$ & 171 & 171 & 171 & 171 \\
\hline \multirow{3}{*}{ CL } & $\begin{array}{c}\text { Pearson } \\
\text { correlation }\end{array}$ & $0.552 * *$ & $0.565 * *$ & $0.362 * *$ & 1 \\
\hline & $\begin{array}{c}\text { Significant } \\
\text { (bilateral) }\end{array}$ & 0.000 & 0.000 & 0.000 & \\
\hline & $\mathrm{N}$ & 171 & 171 & 171 & 171 \\
\hline
\end{tabular}

Note: ** significant at the .01 level of correlation (bilateral)

In order to verify accurately all of the assumptions, the study used regression analyses to verify assume relationship in model. Researching conducted hierarchical regression analysis and results reporting: First report includes only control variables (collaboration time $\mathrm{CT}$, logistics provider number SQ, country do CO and enterprise scale FS) regression model analysis (model 1); followed reports contain control and independent variables (economic relational investment ERI, the structural relational investment SRI, Chinese-style relational investment CRI, and economic relations investment square ERI2) regression model analysis (model 2). Table 3, Table 4 and Table 5 shows the results of the regression analysis.

Table 3 summarizes the model

\begin{tabular}{|c|c|c|c|c|c|}
\hline Model & R & R Square & $\begin{array}{c}\text { Adjusted } \\
\text { R-squared }\end{array}$ & $\begin{array}{c}\text { Standard } \\
\text { error of } \\
\text { estimate }\end{array}$ & $\begin{array}{c}\text { Durbin- } \\
\text { Watson }\end{array}$ \\
\hline 1 & $0.782 \mathrm{a}$ & 0.611 & 0.603 & 0.61711 & \\
\hline 2 & $0.893 \mathrm{~b}$ & 0.797 & 0.767 & 0.48793 & 1.825 \\
\hline
\end{tabular}

Notes: a. predictor variables: (Constant), FS, CT, CO, SQ. b. Predictors: (Constant), FS, CT, CO, SQ, SRI, CRI, ERI2, ERI. c. dependent variables: $\mathrm{CL}$

Table 4 variance analysis

\begin{tabular}{|c|c|c|c|c|c|c|}
\hline \multicolumn{2}{|c|}{ Model } & $\begin{array}{c}\text { sum of } \\
\text { squares }\end{array}$ & df & $\begin{array}{c}\text { Mean } \\
\text { Square }\end{array}$ & F & Sig. \\
\hline \multirow{4}{*}{1} & Regression & 20.705 & 4 & 5.17625 & 19.883 & $0.000 \mathrm{a}$ \\
\cline { 2 - 7 } & Residuals & 43.216 & 166 & 0.260 & & \\
\cline { 2 - 8 } & Total & 63.921 & 170 & & & \\
\hline \multirow{3}{*}{2} & Regression & 25.353 & 8 & 3.169 & 13.311 & $0.000 \mathrm{~b}$ \\
\cline { 2 - 7 } & Residuals & 38.568 & 162 & 0.238 & & \\
\cline { 2 - 8 } & Total & 63.921 & 170 & & & \\
\hline
\end{tabular}

Notes: a predictor variables: (Constant), FS, CT, CO, SQ. b Predictors: (Constant), FS, CT, CO, SQ, SRI, CRI, ERI2, ERI. c dependent variables: CL

Table 5 A regression coefficients

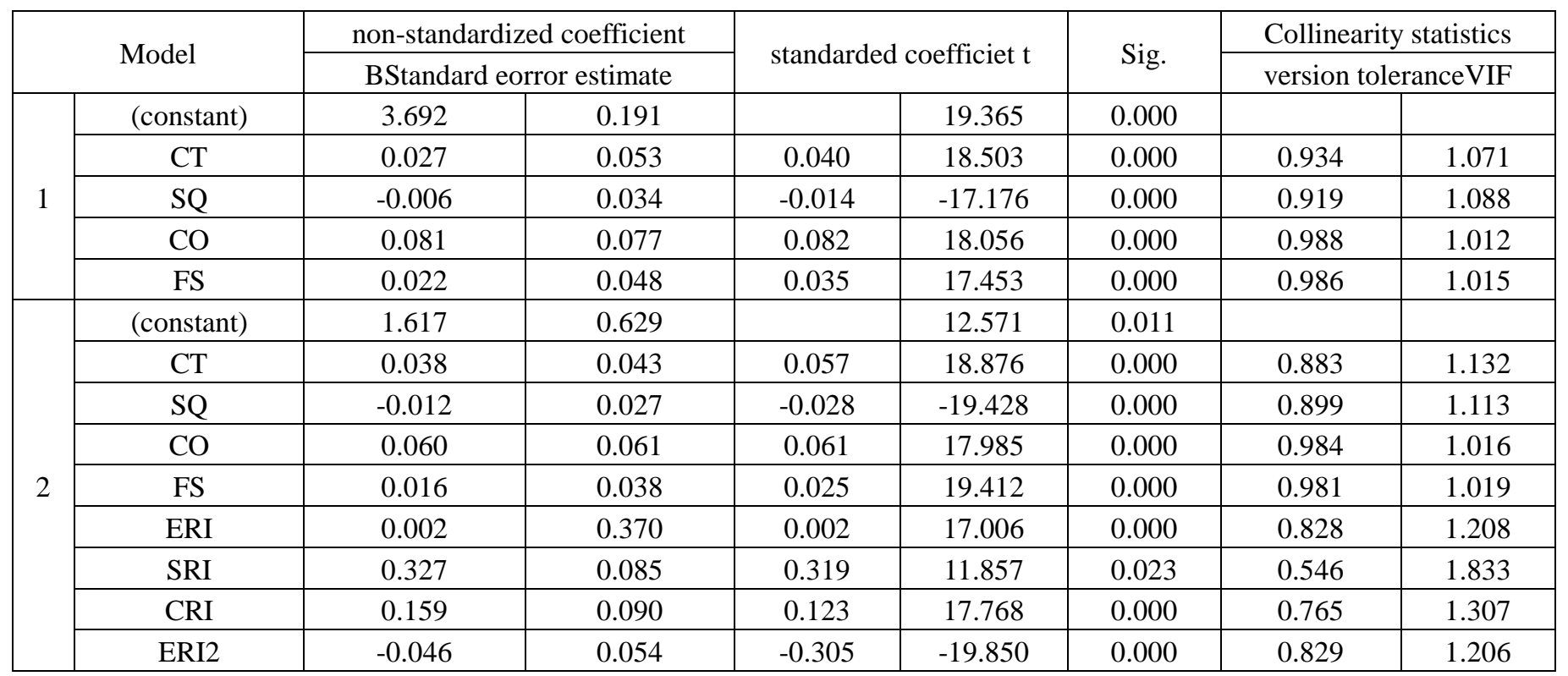

Note: a dependent variable: $\mathrm{CL}$

Table 3 shows that joining the independent variables in the model such as economic relations investment (ERI), the structural relational investment (SR), Chinese-style relational investment (CRI) and economic relations investment square (ERI2), the explain extent of the dependent variable to the independent variable rosing by $60.3 \%$ to
$76.7 \%$, indicating that adding independent variable can significantly improve explanatory power of the regression model.

Table 4 shows that significant coefficients of model 1 and model 2 are less than 0.01, therefore, Model 1 (collaboration time CT, logistics provider number SQ, country CO and enterprise scale FS) and 
Model 2 (collaboration time CT, logistics providers number SQ, country $\mathrm{CO}$, enterprise scale FS, economic relations investment ERI, structural relational between investment SRI, Chinese-style relational between investment and economic relations investment CRI square ERI2) are established.

Table 5 shows that economic relational investments' A coefficient is greater than 0 (coefficient of 0.002), quadratic coefficient is less than 0 (coefficient of -0.305), while the coefficient is significant, therefore, there is a significant inverted U-shaped impact between economic relational investments and customer loyalty, Hypothesis 1 was supported. The structural relational investment coefficient greater than 0 (coefficient of 0.319), and significant, therefore, the structural relational investment has a significant positive impact on customer loyalty, Hypothesis 2 was supported. Chinese-style relational investment coefficient greater than 0 (coefficient of 0.123 ), and significant, therefore, Chinese-style relational investments has significant positive impact on customer loyalty, Hypothesis 3 was supported.

\section{CONCLUSIONS AND MANAGEMENT IMPLICATIONS}

From the analysis above that we know: (1) there was $\mathrm{U}$ shape correlation between economic relational of TPL enterprise and customer loyalty; It notes that TPL enterprises should pay attention to a degree when they cut prices, discounts to their customers in the marketing when they carry economic relational investments, before reaching a certain amount of investment, benefits are growing with increasing of investment, but there is investment efficiency decreased if a certain amount is reached. So, enough is enough in order to produce the best results. (2) There was a positive correlation between structural relational investments of TPL enterprise and customer loyalty; it notes that Establish the structural relational such as rules, contracts, etc. will help improve customer loyalty. (3) Chinese guanxi investment of TPL enterprise is required to continue to strengthen in the framework of moral and law, can continuously improve customer loyalty.

There are a positive correlation between Chinesestyle relational investments and customer loyalty $\mathrm{OF}$ TPL enterprises. Description of Chinese-style relational investments such as communication, empathy, gifts and other match up between investment forms can improve customer loyalty, which apply for a Chinese saying goes: people do not blame. However, this investment must be based on the level of policy and legal permission, otherwise both TPL enterprise itself and customers have an adverse impact.

\section{INADEQUATE AND PROSPECT}

In this study, the deficiencies are following: First, this study only considers the TPL enterprise, enterprise scale cannot be considered as an adjustment variable, because if re-grouped according to the manipulated variable, the number of samples in each group will become less, so get lack of representative and typical sample may make findings of instability; Secondly, this study did not investigate the relational between different types of TPL enterprises to invest in the relational between customer loyalty read. Following aspects as issues for further study in the future: First, consider a large sample of different types and different sizes of factors; Second, a number of third-party logistics companies started the relational between different types of investment tracking study reveals investment on the relational between different types of customer loyalty, we should provide practical support for the follow-up business by lessons learning.

\section{ACKNOWLEDGEMENT}

Fund by Humanities and Social Sciences general project of Guangdong Province, Code [2013WYXM0167]

\section{REFERENCES}

[1] Balakrishnan, A, \& Geunes, J. Collaboration and coordination in supply chain management and e-business. Production and Operations Management, 2004, 13(1).

[2] Bensaou M, Anderson E. Buyer-supplier relations in industrialmarkets: do buyers risk making idiosyncratic investments? Organization Science, 1999, 10(4); 460-481.

[3] Lin et. Building Trust between growers and market agents. Supply Chain Management, 2003, 8(1): 65-78.

[4] Frederick and Schefter. Power and Interdependence in Buyer-Supplier relationals: A Purchasing Portfolio Approach, Industrial Marketing Management, 2000, 36(2), 219-229.

[5] Peltier and Westfall, Customer loyalty and customer relationship life cycle Management Engineering, 2000, 17(12):90-93.

[6] Colwell et al . Third-party logistics service providers and enterprise customers shared savings contracts. Systems Engineering Theory and Practice, 2006, 27 (2): 46-53.

[7] Qianli Dong, Based third party logistics strategic supply chain management China Soft Science, 2000 (10): 34-38.

[8] Xuemei Fan, Customer relationship management strategy constitute research and implementation of third-party logistics Economic Research Guide, 2012 (11): 167-168. 